\title{
European Commission, trade agreements and diversity of cultural expressions: Between autonomy and influence
}

European Journal of Communication 2016, Vol. 31(4) 446-46I

(C) The Author(s) 2016 Reprints and permissions: sagepub.co.uk/journalsPermissions.nav DOI: I0.1 I77/0267323 I I6655506 ejc.sagepub.com

@SAGE

\section{Antonios Vlassis}

University of Liège, Belgium

\begin{abstract}
The Convention on diversity of cultural expressions - adopted by United Nations Educational, Scientific and Cultural Organization in 2005 - is a main international instrument within the global governance of cultural and audiovisual industries. For its part, the European Commission played a critical role in the negotiation, leading to the Convention on Diversity of Cultural Expressions' adoption. In this respect, the article aims to explore why and how the Commission uses the Convention on Diversity of Cultural Expressions throughout the recent European Union trade negotiations, for which purposes and how the Convention on Diversity of Cultural Expressions influences the European Union foreign policy and its objectives. The article is more concerned with analysing the policy process through which the Commission's strategy is formulated in light of the Convention on Diversity of Cultural Expressions and of the place of cultural and audiovisual industries within the European Union trade agreements and also concerned with understanding whether the Commission's autonomy is transformed into influence within the policy process.
\end{abstract}

\section{Keywords}

Cultural expressions, digital services, EU audiovisual policies, trade agreements, cultural cooperation

The Convention on Diversity of Cultural Expressions (CDCE) - adopted by United Nations Educational, Scientific and Cultural Organization (UNESCO) in 2005 - has so far received the membership of 143 States and of the European Union (EU). On one

\section{Corresponding author:}

Antonios Vlassis, Center for International Relations Studies (CEFIR) and Fonds National de la Recherche Scientifique (FNRS), University of Liège, Quartier Agora, Place des Orateurs 3, boîte 384000 Liège, Belgium. Email: antonios.vlassis@gmail.com 
hand, the CDCE is now a main international instrument within the global and multi-level governance of cultural and audiovisual industries. It recognizes primarily the importance of cultural public policies for the diversity of cultural expressions, as well as the specificity of cultural goods and services. The CDCE is also credited with integrating culture in the development policies and with reinforcing the international cultural cooperation. On the other hand, the CDCE, as a hard law instrument with a soft normative content (Vlassis, 2011), gives important leeway to the Parties on sensitive issues, such as the appropriate cultural policies for the diversity of cultural expressions or the interface 'trade-culture' (p. 495). The EU played a critical role in the negotiation, leading to the CDCE's adoption. In 2006, Jan Figel, European Commissioner in charge of 'Education and Culture', stated that the ratification of the CDCE is the last step in the long process of sometimes very tricky negotiations, for which the Commission was responsible as the voice of the Community.

In this respect, the article addresses the question of the European Commission's (hereafter Commission) capacity to act within the global governance of cultural industries, and in particular of its ability to promote the CDCE within the EU trade agreements. The aim is to explore why and how the Commission uses the CDCE throughout the recent EU trade negotiations, for which purposes and how the CDCE influences the EU foreign policy and its objectives. More concretely, I deal with the political action of the Commission because it plays - as the agent of the EU with a right to initiate policy proposals and implement policy decisions - an overarching role in defining, defending and promoting the EU's interests.

An academic research recently offers useful insights on the interactions between the CDCE implementation and the EU. It deals with key issues such as the regulation of the 'trade and culture' interface and the EU's role (Neuwirth, 2013; Psychogiopoulou, 2014), the EU protocols on cultural cooperation and their impact on the CDCE implementation (Loisen and De Ville, 2011; Richieri Hanania, 2012; Souyri-Desrosier, 2014), the EU actions for implementing the CDCE within the European cultural landscape (Lickova, 2014; Richieri Hanania and Ruiz Fabri, 2014), as well as the interregional cooperation related to the audiovisual sector with special focus on the links between EU and Mercosur (Canedo and Crusafon, 2014; Sarikakis and Ganter, 2014).

Although recent scholarship on the CDCE has sufficiently explored the interplay between global governance of cultural industries and EU's practices, it emphasizes the 'singleness' and 'unitariness' of the EU. The above literature, hence, focuses on policy outcomes rather than on policy process and it assesses the overall impact of the EU in the external cultural affairs. In doing so, it seems to overestimate the evolving EU's influence in global cultural politics. Conversely, my article is more concerned with analysing the key dynamics through which the Commission's strategy is formulated in light of the CDCE and of the place of cultural and audiovisual industries within the EU trade agreements and with highlighting whether the Commission's autonomy is transformed into influence within the policy process. In this sense, it emphasizes empirically not only the Commission's interests and strategies about the CDCE and its place in the EU trade agreements but also the Commission's autonomy vis-à-vis the national governments, the interactions between the Commission and the EU culture organizations of professionals, as well as the EU inter-institutional dynamics (Vlassis, 2015a, 2015b). 
The article - based on document analysis and on 11 semi-structured interviews with the actors involved ${ }^{1}$ - consists of four main parts. First, it provides an analysis of the Commission's role within the negotiations, leading to the CDCE adoption. Second, it focuses on the initiative of the Commission to include a Protocol on Cultural Cooperation in the EU trade agreements. Third, it sheds light on the policy process through which the Commission's mandate towards the negotiations on the Transatlantic Trade and Investment Partnership (TTIP) between the EU and the United States is made. Finally, it highlights the principal features of the current EU debate on the definition of the new media non-linear services.

\section{A supranational actor within the international cultural affairs}

Since 2003, the Commission has been involved in the establishment of an international policy tool on cultural industries, producing a communication entitled 'Towards an International Instrument on Cultural Diversity' (European Commission, 2003). Following a bargaining between the EU member states, the European Parliament and the Commission, the latter enjoyed the expanded observer status at the UNESCO for the first time, participating in the negotiations on the CDCE. As a result, the EU participated as a single entity within the intergovernmental UNESCO arena, speaking with two voices during the negotiations, that of the Commission and that of the Presidency of the Council (Psychogiopoulou, 2012: 376). The Commission's role was especially to ensure consistency between the CDCE and the body of the EU legislation and norms (the so-called acquis communautaire), maintaining the EU and member states' 'capacity to define and implement their cultural and audiovisual policies for the purpose of preserving their cultural diversity' (Council of the European Union, 2004). In other terms, the protection of the internal cultural acquis allowed the Commission to attain external competences towards cultural affairs (Vogler, 2011: 374), insofar as an international normative evolution would have internal consequences on the EU cultural and audiovisual policies. In this regard, the Commission was recognized as a leading actor for the CDCE's adoption, having an integrating effect on the EU member states' interests (Vlassis, 2015a: 250-256).

The EU, as party to the CDCE, has the formal right to implement the Convention in the same way as the member states. The 'European Agenda for culture in a globalizing world', launched by the Commission in 2006 and adopted in 2007, is the first policy framework for culture at EU level. It recognizes explicitly the EU as a cultural actor in external relations and it claims a leading role for the EU with respect to the CDCE's norms. The Agenda is based on the provisions of the CDCE, seen as an integral instrument of the acquis. One of the objectives of the Agenda includes the enhancement of the role of culture in the EU's external relations and the promotion of the CDCE at international level (European Commission, 2007: 10). In accordance with the European Agenda, the 'Cannes declaration' acknowledged in 2008 'the utility of reinforcing audiovisual cooperation measures in the cooperation and trade agreements concluded between the European Union and third countries' (European Commission, 2008: 2), and it was followed by the Commission's working document on the 'External Dimension of Audiovisual Policy'. 


\section{The translation in practice of international norms}

The Protocol on Cultural Cooperation (hereafter protocol) is a new policy instrument elaborated by the Commission in order to promote the CDCE's implementation through the bilateral trade agreements. Since 2008, the Commission has introduced in total four protocols: ${ }^{2}$ the protocol with the CARIFORUM ${ }^{3}$ included in the Economic Partnership Agreement between EU and CARIFORUM and signed in 2008; the protocol with South Korea included in the EU-Korea Free Trade Agreement (FTA) and concluded in 2009; the protocol with the countries of Central America (CA) ${ }^{4}$ concluded in 2010 separately from the Association Agreement between EU and CA signed in 2012; the 2011 protocol with the Andean countries Peru and Colombia that was concluded separately from the FTA between EU and Peru/Colombia. ${ }^{5}$

All the protocols make explicit reference to the CDCE, using its definitions on several concepts such as cultural diversity, cultural expressions or cultural goods and services. The protocols also recognize the importance of the cultural policies and the twofold economic and cultural nature of cultural goods and services. Furthermore, they stipulate that the countries, not having yet ratified the CDCE, intend to do so expeditiously. As a result, Barbados ratified the CDCE in 2008; the Dominican Republic, Grenada, Guyana, St Vincent and the Grenadines in 2009; Haiti, Trinidad and Tobago, Honduras and the Republic of Korea in 2010; Costa Rica in 2011; Colombia, Antigua and Barbuda and El Salvador in 2013; Bahamas in 2014; Belize and Dominica in 2015; as well as St Kitts and Nevis in 2016. ${ }^{6}$ Moreover, the protocols aim to promote the CDCE's norms in EU's external relations (Troussard et al., 2012), and especially the CDCE Articles 12 (Promotion of International Cooperation), 14 (Cooperation for development), 15 (Collaborative arrangements) and 16 (Preferential treatment for developing countries). In this sense, the protocols translate more broadly the framework of the CDCE, beyond the dichotomy 'inclusion or exclusion' of cultural goods and services within the trade negotiations. They represent both a bridge between the trade and culture normative spheres and a strategic split with the cultural exception (exception culturelle). ${ }^{7}$

All the protocols seek the reinforcement of the cooperation in three specific areas: (1) each Party shall facilitate, with conformity with its legislation, the entry into and temporary stay into its territory of artists and other cultural professionals and practitioners from another Party; (2) the EU Party shall provide technical assistance for the development of cultural industries of the developing signatory countries, the design and the implementation of cultural policies and the promotion of the production and exchange of cultural goods and services; (3) the Parties shall encourage 'audiovisual, including cinematographic cooperation', namely, new co-production agreements, access of co-productions to the markets of signatories, promotion of shooting cinematographic films and TV programmes in the territories of Parties (see CARIFORUM-EU, 2008; Republic of Korea-EU, 2011).

\section{The protocol on cultural cooperation as a top-down instrument}

The initiative of the Commission meets two main challenges, illustrating the limits of its autonomy. The adoption of the protocol is largely due to the Commission's initiative in 
order to promote the CDCE and to improve its negotiating position. This means that the protocol was based on a top-down approach, elaborated by the Commission without taking into consideration the European professional organizations in cultural sector or the political willingness of national EU governments.

First, this approach restrained the capacity of the Commission to anticipate that the protocol between EU and South Korea would be the source of a big controversy. The main organizations of culture professionals (French Coalition for the Cultural Diversity, 2009; International Network on Cultural Diversity (INCD) Europe, 2009) and the French government expressed strong reluctance towards the EU-Korea protocol, pointing out that the latter was not in conformity with the CDCE and with the commitments of the Commission in favour of the diversity of cultural expressions. Therefore, they denounced that the Commission intended to include the cultural industries within the FTA agenda in order to use them as a selling point for proceeding with trade deals and gain concessions in other economic areas. According to Yvon Thiec, Chairman of the INCD Europe and of the European TV and Cinema Producers Association (Eurocinema), 'the protocol EU/ Korea cannot serve as a model for cultural cooperation and needs to be refurbished' (INCD Europe, 2009).

In fact, the protocol created a win-win situation within the Commission. The Directorate General (DG) 'Education and Culture' with a culture-driven orientation, undertook to promote the CDCE in EU external affairs and to establish a policy tool for the CDCE implementation. Less well known, perhaps, was that the protocol was beneficial for the signatory developing countries obtaining access to the preferential regulatory and financial EU cultural policies, and therefore, it gave important leeway to the DG Trade negotiators:

The Commission's strategy was consistent with the promotion of the CDCE and the trade negotiators had also a real interest. The Commission promoted the cultural cooperation on one side, and on the other the EU negotiators had the possibility to obtain favoured treatment regarding other major EU sectors, such as the telecommunications or the intellectual property. (Interview with a senior official, European Commission, 16 January 2015)

As a result, in 2009, a working group composed of representatives of the concerned French official departments and of French culture organizations published an official document on specific proposals for the EU foreign cultural policy (France, 2009). 'In an attempt to conciliate national cultural policies and international cultural exchanges' (Richieri Hanania, 2012: 448), the working group recommended the setting up of negotiation teams taking into account the specific needs of the cultural sector and the dissociation between FTA and protocols. Ultimately, the content of the protocol should be in conformity with the level of development of each partner, its international commitments and its geographical location, as well as the development of its cultural industries.

In other terms, whereas the protocol between EU and CARIFORUM was conceived as an agreement for promoting the interregional cultural cooperation, the protocol between EU and South Korea was strongly criticized because of Korea's international commitments and of the developed level of Korean audiovisual industry. In this respect, the latter should not be subject to the CDCE Articles on cultural cooperation and 
especially to Article 16 on preferential treatment for developing countries. In 2009, the Korean film production was 138 - more than the films produced in Italy or in the United Kingdom - and the market share for Korean films was $48.8 \%$. The total admissions were 156.8 million, while the 2009 admissions reached 146.3 million in Germany, 111.2 million in Italy and 109.5 million in Spain (European Audiovisual Observatory, 2010). In addition, in the context of the US-Korea FTA (KORUS FTA) approved in 2011, the Korean government, despite the serious concerns of the Korean cinema professional organizations, ${ }^{8}$ reduced the screen quotas from 146 motion pictures per year to 73 . Finally, South Korea is one of the 36 World Trade Organization (WTO) members that took commitments in the audiovisual sector.

Second, the top-down building of the protocols hinders the effective implementation of their provisions, leaving aside the main actors of the implementation, such as the EU national governments and the EU culture organizations. As regards the protocol between EU and CARIFORUM, the European Centre for Development Policy Management (2011) emphasized,

The eight EU Member States interviewed had not adopted any specific measures to implement the protocol's provisions. Existing or upcoming measures were not a result of the protocol, but rather a continuation of their existing cultural cooperation policies with third countries (p. 18)

concluding that 'there is a lack of awareness on the side of the European cultural sector of the potential opportunities to cooperate with the CARIFORUM cultural sector'.

In the same vein, the Domestic Advisory Group established by the Commission for evaluating the results of the implementation of the protocol with South Korea noted 'the lack of EU-Korea audio-visual co-productions under the conditions mentioned in the protocol', and it pointed out that 'there is a need to promote the protocol at industry, state and EU level if the entitlement for EU-Korean co-productions is to be properly exploited' (European Commission, 2014: 2).

Here, it's worth mentioning that the Centre national du cinema (France) was reluctant towards the protocol with South Korea insofar as national actors have historically jealously guarded the audiovisual co-productions area. France is the only EU country having signed a film co-production agreement with South Korea in 2006. France is also the EU leading country in the audiovisual co-productions, signing in total 45 bilateral co-production agreements, while Germany has signed 18, Spain 17 and the United Kingdom 13 (Scoffier, 2014). In addition, throughout the period 2005-2013, 60 films were co-produced between South Korea and non-EU countries, whereas since 2007 no film has been co-produced with any EU country, apart from France (Le Sourd et al., 2012: 69).

\section{Transatlantic partnership and digital cultural services: The Commission's autonomy under pressure}

The negotiations on the TTIP - supposed to become the world's largest free trade area - is a real test for the Commission's actorness and for the treatment of cultural goods and services by the FTAs in the digital era. 
In the context of the information technology revolution, one of the major US diplomacy priorities is to include the digital services in the agenda of FTAs (Vlassis, 2014, 2015b). More specifically, the digital technologies offer innovative ways of providing the cultural content over electronic networks and they even complicate the demarcation between content and transmission. The US administration is no longer seeking to challenge the financial and regulatory capacity of governments in the field of the "traditional' cultural services, such as movie theatres, physical video services and conventional television (Vlassis and Richieri Hanania, 2014: 32-35). However, it aims at preventing the implementation of regulatory measures in the on-demand audiovisual media services, such as catch-up TV services, branded channels of broadcasters on open platforms and video-on-demand film services, which represent a strong potential of growth. According to the US administration, the above services are an integral part of the e-commerce or ICT (Information and communications technology) sectors. Thus, they have nothing to do with culture, and any regulation must be 'the least restrictive on trade, non-discriminatory and transparent', promoting 'an open market environment' (US Congress, 2014: 18).

More concretely, from 2009 to 2013, the worldwide audiovisual revenue growth of four leading US Internet players is massive: Apple iTunes division increased from USD4 billion to USD16 billion; Amazon (sales audiovisual media) from USD7.6 billion to USD13 million; YouTube from USD0.5 billion to USD5.6billion; Netflix from USD1.6 billion to USD4.3 billion (Grece et al., 2015: 17). Moreover, the US surplus in cross-border trade in audiovisual services totalled USD13.6 billion in 2012 (USD11.4 billion in 2008). The United Kingdom, Germany and the Netherlands are leading destinations, representing $40 \%$ of the US exports of audiovisual services in 2012 (US International Trade Commission, 2014: 57-62). Overall, 'Europe is, by far, the largest regional consumer of US audiovisual services exports, accounted for about $61 \%$ of such exports in 2012' (US International Trade Commission, 2014: 60), thereby revealing that the European film market is still an integrated feature of the Hollywood economy (Thiec, 2003: 121).

In June 2013, 27 EU governments agreed on the exclusion from the Commission's mandate of the audiovisual services in the negotiations with the United States. Nevertheless, it should be noted that there is no consensus within the EU regarding the cultural exception. Clearly, the debate highlighted, once again, a political gap between two divergent positions and it illustrated an institutional schizophrenia within the EU (Panebianco, 2006). The interventionist position favoured the total exclusion of audiovisual services from the trade negotiations, thus recognizing the social, identity and cultural aspects of the regulative mechanisms on the digital audiovisual services. The second position put forward the argument that the Commission should not exclude from its mandate as many commercial areas as these would strengthen its negotiating power and would ensure a mutual relationship with the United States. In fact, it emphasized the primacy of the consumer's interests, the innovation policy as well as the beneficial effects of the economic competitiveness in the cultural sector. To wit, the first position aimed to protect the policy space over cultural and audiovisual goods and services and the second one to enlarge the negotiating space vis-à-vis the US administration. 
On one hand, the interventionist position was widely supported by France, Italy, several European Ministries of Culture, the European Parliament, as well as the culture professionals' organizations. In May 2013, the French Minister of Culture and Communication, Aurèlie Filippetti, published a letter addressed to the Irish EU presidency and to the Commission in favour of the cultural exception. As a Commission's official stated, 'According to the French point of view, a party to the CDCE must not take commitments regarding the cultural industries in the context of FTAs. It's a rigid conception' (Interview with a senior official, European Commission, 16 December 2014). The letter was cosigned by the Austrian, Belgian, Bulgarian, Cypriot, German, Hungarian, Italian, Polish, Portuguese, Romanian, Slovenian, Slovak and Spanish culture ministers. Furthermore, the European Parliament voted a resolution asking, 'cultural and audiovisual services, including online ones, be excluded from the negotiating mandate, in order to protect the cultural and linguistic diversity of EU countries (381 votes to 191 with 17 abstentions)' (European Parliament News, 2013). Significantly, in July 2015, a new resolution of the European Parliament on the TTIP recommended the Commission to ensure in full compliance with the CDCE that the parties 'reserve their right to adopt or maintain' any financial or regulatory measure in the cultural sector, 'irrespective of the technology or distribution platform used' (European Parliament, 2015). Hence, the Parliament sees a red line in the exclusion of audiovisual services and also a condition for the future ratification of the TTIP. Finally, in April 2013, under the initiative of the Belgian filmmakers Luc and JeanPierre Dardenne, the organizations of audiovisual and culture professionals launched a petition 'The cultural exception is not negotiable', raising over 8000 signatories.

On the other hand, it should be mentioned that a coalition of actors, led by the United Kingdom and the majority of the European commissioners, benefiting from the support of most 'Northern' EU states, of the majority of Ministries of Economy and Trade, as well as of the telecommunications operators and the big Internet companies, foresaw the inclusion of cultural services in the TTIP's agenda and the economic regulation of the audiovisual sector as a source of fostering EU growth:

The issue was clear for many EU member states. They had to defend leeway for the implementation of policies on the digital cultural services, whereas this leeway would be hypothetically used in the future. So, the digital cultural exception is not an issue affecting vital interests today, but hypothetical interests in the future. (Interview with a senior official, European Commission, 16 December 2014)

More precisely, in mid-March 2013, the Commission decided to include the audiovisual services in its draft mandate for the TTIP negotiations:

Since the negotiations on the CDCE in 2003, the Commission has attempted to elaborate a strategic vision on cultural affairs. The Commission's mandate was a choc for some DGs, a brutal split from our previous principles. The personality and views of the EU Commissioner for Trade were crucial for the final decision. (Interview with a senior official, European Commission, 9 January 2015)

Only three EU Commissioners, namely, Androulla Vassiliou, Commissioner for Education and Culture, Michel Barnier, Commissioner for Internal markets and 
Services, as well as Antonio Tajani, Commissioner for Industry and Entrepreneurship, came out against the inclusion of sensitive areas such as the audiovisual sector in the mandate (Inside US Trade, 2013). It's noteworthy that in August 2013, the Commissioner for Trade Karel De Gucht, in his written answer to the parliamentary question of the Portuguese member of the European Parliament Diogo Feio (European People's Party), stressed,

the EU has made commitments as part of the UNESCO CDCE. The question is not whether cultural diversity must be defended in the negotiations on a new partnership for trade and investment with the United States (TTIP), but what is the best way to do this. (European Parliament, 2013)

As a result, in the context of the on-going global negotiations, there is a strong pressure among numerous interdependent areas creating a potential risk for the digital cultural services to be subject to concession. Finally, it should be noted that in October 2014, the European Council decided to declassify the TTIP negotiating directives. This decision is strongly linked both to the European Parliament and civil society's criticisms on the undemocratic and non-transparent nature of the EU trade diplomacy and to the rejection by the European Parliament of the Anti-Counterfeiting Trade Agreement in 2012 with the result that the entire EU remained outside of the agreement.

\section{The debate is far from over: To define or not to define?}

Undoubtedly, the Commission undertakes to protect the acquis communautaire covering the conventional cultural services. It is revealing that throughout the period 1996-2016, 18 governments out of the 27 new WTO members agreed to make commitments in the audiovisual sector:

The Commission has a problem within the WTO because its position on the audiovisual services is defensive. In other terms, it's a no position. In this sense, it's not possible to prevent other countries from taking commitments in the audiovisual sector. This would be against the WTO principles. The US position, by contrast, is more dynamic and consistent to the WTO framework. (Interview with a senior official, European Commission, 12 January 2015)

Among the nine new WTO members not being subject to certain restrictions, sevenAlbania, the former Yugoslav Republic of Macedonia, Estonia, Latvia, Lithuania, Moldavia, Ukraine - were likely to respect the acquis on the audiovisual services defended by the Commission within the WTO.

Even so, the current issue is the establishment of a consensual definition of the new, non-linear media services recently developed and largely unregulated. In this respect, the final place of this type of services in the trade agreements highly depends on the evolutions within other institutional contexts.

In March 2015, the European Court of Justice (ECJ) ruled that France and Luxembourg couldn't apply a reduced rate of VAT (value-added tax) to the supply of digital books, contrary to paper books. According to the Commission, both countries failed to fulfil their obligations under the VAT Directive. The ECJ upheld the Commission's position 
pointing out that the VAT Directive Annex III regarding the reduced rate refers in particular to the 'supply of books ... on all physical means of support', on one side, and 'the VAT Directive excludes any possibility of a reduced VAT rate being applied to electronically supplied services', on the other (ECJ, 2015). This means that the ECJ - being one of the agenda-setter in the development of the EU audiovisual media policy influencing the outcome of the EU legislative process in that area (Arena, 2014: 218) - affirmed not only the distinction between physical and electronic cultural services but also that the digital books should not be considered as cultural services, thus not being subject to the same regulative framework as physical books.

Moreover, today's EU agenda on audiovisual services is dominated by the review of the 2007 Audiovisual Media Services Directive (AVMS). The 2007 AVMS was 'a victory for liberal economic forces but it contains cultural considerations' (Iosifidis, 2011: 163). The Directive also affirmed the 'doubtful' distinction between 'new and older modes' of culture service delivery, which provoked diverse criticisms (Pauwels and Donders, 2014: 531-540). In 2014, the Council of EU Ministers of Education and Culture adopted conclusions on the European audiovisual policy in the digital era, inviting the Commission to 'assess whether the current regulatory distinction between non-linear and linear audiovisual media services is still appropriate in the context of digital era' (Council of the European Union, 2014). As argued by the Lescure (2013) Report of the French Ministry of Culture, the distinction between 'traditional services' and 'new services' is 'artificial' and its use would mean 'the death sentence of EU cultural and audiovisual policies, which would be confined only to traditional cultural services'. It is, hence, crucial to maintain 'a sole treatment to audiovisual services, in accordance with the principle of technology neutrality’ (Lescure, 2013: 170).

Yet the European Commission's (2013) Green Paper on a 'Fully Converged Audiovisual World: Growth, Creation and Values' prepared by DG 'Communications Networks, Content and Technology' did not make any reference to the CDCE stating that the distinction between linear and non-linear services is 'based on the much higher degree of consumer control in on-demand services, justifying less stringent regulation in certain areas' (European Commission, 2013: 11). On its turn, the European Parliament's resolution on the Green Paper regretted 'the lack of a specific reference to the dual nature of audiovisual media as cultural and economic assets [...] and reminds the Commission that the EU is committed to the UNESCO CDCE' (European Parliament, 2014).

To this picture it should be added that France, Canada and Belgium, in collaboration with expert groups, ${ }^{9}$ are recently undertaking to adapt the CDCE to the digital challenges and to integrate operational guidelines on digital issues and diversity of cultural expressions (UNESCO, 2014: 25). The objective is to align the CDCE's norms to the development of new technologies and to ensure the public cultural policies and the dual nature of cultural goods and services within the digital environment.

\section{Concluding remarks}

By examining FTAs and the CDCE implementation, my article illustrated four points regarding the Commission's practices and its influence. First and foremost, the Commission conducted a principled foreign policy in terms of culture, especially using regional 
cooperation as the main way to transpose the CDCE norms. One need not go quite this far to recognize that the CDCE legitimized an increasing involvement of the Commission in EU cultural external affairs and it offered an opportunity for the Commission to establish itself as a foreign policy actor in cultural affairs. As reflected by the Protocol on Cultural Cooperation, this allowed the Commission to elaborate a strategic vision and reinforce its autonomy, building a linkage between the diversity of cultural expressions and several geopolitical or economic stakes. To some extent, the Commission used trade tools in pursuit of playing a key role for the promotion of the CDCE norms in third countries and it expressed clear preference to the normative basis of the global governance of culture.

Instead, the Commission's action lacks social support. The protocol and the TTIP Commission mandate illustrated a top-down strategy approach without strong links to the EU culture organizations of professionals. The latter have little trust in the Commission's purposes to promote the normative core of the CDCE - in Europe and at international level. The article placed emphasis on this disconnect between Commission and the EU culture organizations, which is a serious constraint for the EU foreign cultural policy effectiveness and for the Commission's influence in external cultural affairs.

Third, even the interpretations on the scope of CDCE are far from convergent, insofar as the Commission translated more broadly the CDCE, beyond the dichotomy 'inclusion or exclusion' of cultural goods and services in the agenda of trade negotiations. More concretely, in a context of technological convergence and digitization, the Commission seeks in the economic competitiveness and innovation policy ground for ensuring the diversity of cultural expressions, thereby questioning the specificity of the digital cultural services. However, this position meets not only the reluctance of several members of the European Council but also the criticisms of the European Parliament, which considers the strong compliance with the CDCE norms as a condition for the development of the EU audiovisual and cultural policy.

The balance between intergovernmentalism method and Community action (Smith, 2011) leads to our fourth point: the influence of the Commission is more consistent with the issue-specific imperatives and with the overarching view of its role in the decisionmaking process. The protocol and the TTIP mandate highlighted that although the Commission has both initiative and executive autonomy, the member states keep powers in the decision-making process. These revealed that the Commission's practices rely on the willingness of member states with strong interests in the cultural affairs. Consequently, the Commission's actorness is linked to the context in which the EU foreign cultural policy is made. Most importantly, France remains a key and prominent actor throughout the agenda setting process on issues related to cultural policies and cultural and audiovisual services and goods. Therefore, the question for future research is not only to investigate the outcomes of the EU as actor in external cultural affairs but also to analyse further the policy process in order to understand who controls the EU authority and power, why and how (Strange, 1996: 161).

\section{Acknowledgements}

The author is grateful to Sebastian Santander, Chrysoula Lentzou and the anonymous peer reviewers for their valuable comments on previous versions. An earlier version of this article was presented at the panel on 'Regional Organizations' of the International Studies Association's 56th 
Annual Convention, New Orleans, 19 February 2015 and at the International Conference 'Cultures, Societies and Digital Technologies', Université du Québec à Montréal (UQAM), 1516 October 2015.

\section{Funding}

The author(s) declared the following potential conflicts of interest with respect to the research, authorship, and/or publication of this article: The author is a full-time researcher of the Fonds national de la Recherche Scientifique (FNRS-Belgium) and this research has been funded through the FNRS post-doc fellowship.

\section{Notes}

1. The results of the interviews will be presented anonymously for reasons of confidentiality.

2. In 2011, the Commission signed also a Joint Program on Culture with the Ministry of Culture of Brazil. This Program set in train a series of initiatives 'aimed at enhancing policy exchanges, in particular linked to the implementation of the CDCE'. The terms of the Program were not so developed like those of the protocol, even if some priorities were the same, such as the promotion of audiovisual co-productions.

3. Antigua and Barbuda, Bahamas, Barbados, Belize, Dominica, Dominican Republic, Grenada, Guyana, Haiti, Jamaica, St Lucia, St Vincent and the Grenadines, St Kitts and Nevis, Suriname, and Trinidad and Tobago.

4. Panama, Guatemala, Costa Rica, El Salvador, Honduras, and Nicaragua.

5. The protocol with CARIFORUM countries has been applied since 2008 and the protocol with South Korea since 2011. Instead, the protocols with Central America and with Peru/Colombia are not yet in force.

6. The only country which has not yet ratified the Convention on Diversity of Cultural Expressions (CDCE) is Suriname. Instead, Jamaica, Peru, St Lucia, Panama, Guatemala and Nicaragua ratified the CDCE before the conclusion of a protocol with the European Union (EU).

7. One of the initial issues of the global governance of cultural industries deals with the treatment of the cultural and audiovisual goods and services within Free Trade Agreements (FTAs). In the 1990s, the US administration pushed for further liberalization of audiovisual services, on one side, and a competing coalition of actors, driven by France and Canada, defended the term of cultural exception in order to recognize the legitimacy of cultural policies, on the other. The objective was to exclude cultural and audiovisual goods and services from the agenda of international negotiations on FTAs such as the last period of negotiations on the General Agreement on Trade in Services of the World Trade Organization (WTO) in 1993, the negotiations on Multilateral Agreement on Investment within the Organization for Economic Cooperation and Development, as well as the negotiations on the FTA between the United States and Canada (1989) and on the North American FTA (1994) between the United States, Canada and Mexico.

8. In November 2011, several Korean professional organizations in cultural sector held a press conference to protest against the imminent ratification of the US-Korea FTA (KORUS FTA), pointing out that this ratification would violate Korean commitments under the CDCE.

9. It's worth mentioning both the International Network of Lawyers for the Diversity of Cultural Expressions based at the Quebec's Laval University, which prepared - with the support of the Government of Quebec - a report presented at the 7th Intergovernmental Committee to the CDCE (December 2013) and the Centre d'études sur l'intégration et la mondialisation based at the Quebec University of Montreal, which published in March 2015 a report conducted on behalf of the Ministry of Foreign Affairs in France about the CDCE and the digital age. 


\section{References}

Arena A (2014) The ECJ as agenda setter in European audiovisual media policy. In: Donders K, Pauwels C and Loisen J (eds) The Palgrave Handbook of European Media Policy. London: Palgrave Macmillan, pp. 218-238.

Canedo D and Crusafon C (2014) The European audiovisual policy goes abroad: The case of inter-regional cooperation with Mercosur. In: Donders K, Pauwels C and Loisen J (eds) The Palgrave Handbook of European Media Policy. London: Palgrave Macmillan, pp. 526-540.

CARIFORUM-European Union (EU) (2008) Protocol III on cultural cooperation. Official Journal of the European Union. Available at: http://www.sice.oas.org/Trade/CAR_EU_EPA_e/ Protocol_III_e.pdf.

Council of the European Union (2014) Councils conclusions on European audiovisual policy in the digital era. EN 16040/14, 25 November. Brussels: Council of the European Union.

European Audiovisual Observatory (2010) Focus-World Film Market Trends. Strasbourg: European Audiovisual Observatory.

European Centre for Development Policy Management (2011) Implementing cultural provisions of Cariforum-EU EPA, How do they benefit the Caribbean cultural sector? Discussion paper 118, 1 June. Maastricht: European Centre for Development Policy Management.

European Commission (2003) Communication from the commission to the council and the European Parliament: Towards an international instrument on cultural diversity. COM/2003/0520 final, 27 August. Brussels: European Commission.

European Commission (2007) Communication from the commission to the European Parliament, the council, the European economic and social committee and the committee of the regions on a European agenda for culture in a globalizing world. COM/2007/0242 final, 10 May. Brussels: European Commission.

European Commission (2008) Cannes declaration: Declaration of European audiovisual affairs ministers and of the European commission member responsible for the information society and media. In: Europe day at the Cannes festival, 19 May. Available at: http://media.cedslovenia.eu/media/news/old/4/9/7/2497.pdf.

European Commission (2013) Green paper: Preparing for a fully converged audiovisual world: Growth, creation and values. COM (2013) 231 final, 24 April. Brussels: European Commission.

European Commission (2014) Proposal for a council decision on the position to be taken on behalf of the European Union as regards the extension of the entitlement to co-productions as provided for in Article 5 of the protocol on cultural cooperation to the FTA between the EU and its member states, of the one part and the Republic of Korea, of the other part. COM (2014) 81 final, 18 February. Brussels: European Commission.

European Court of Justice (ECJ) (2015) France and Luxembourg cannot apply a reduced rate of VAT to the supply of electronic books, in contrast with paper books. Judgments in Cases C-479/13 and C-502/13, 5 March. Luxembourg: European Court of Justice.

European Parliament (2013) Parliamentary questions, answer given by Mr De Gucht on behalf of the Commission. E-007216/2013, 14 August. Brussels: European Parliament.

European Parliament (2014) Resolution on 'Preparing for a fully converged audiovisual world'. Strasbourg: European Parliament. Available at: http://www.europarl.europa.eu/sides/getDoc. do?pubRef=-//EP//TEXT+TA+P7-TA-2014-0232+0+DOC+XML+V0//EN.

European Parliament (2015) Resolution on the negotiations for the Transatlantic Trade and Investment Partnership (TTIP). Strasbourg: European Parliament. Available at: http:// www.europarl.europa.eu/sides/getDoc.do?pubRef=-//EP//TEXT+TA+P8-TA-2015$0252+0+\mathrm{DOC}+\mathrm{XML}+\mathrm{V} 0 / / \mathrm{EN}$. 
European Parliament News (2013) EU/US trade talks: Keep Parliament on board, MEP's warn (Press release), 23 May. Available at: http://www.europarl.europa.eu/news/en/newsroom/20130520IPR08593/EUUS-trade-talks-keep-Parliament-on-board-MEPs-warn.

France (2009) For a new European Union external cultural strategy. Paris: French Republic. Available at: http://www.diplomatie.gouv.fr/fr/IMG/pdf/2009-12-21_Communication_France_ Strategie_culturelle_exterieure_ENG.pdf.

French Coalition for the Cultural Diversity (2009) The French coalition on cultural diversity is worrying about the FTA negotiations with South Korea and calls for an autonomous discussion on cultural affairs (Press release), 18 March. Available at: http://www.coalitionfrancaise. org/.

Grece C, Lange A, Schneeberger A, et al. (2015) The development of the European market for ondemand audiovisual services. Strasbourg: European Audiovisual Observatory. Available at: http://www.europacreativamedia.cat/rcs_auth/convocatories/FINALREPORT-Thedevelopm entoftheEuropeanmarketforon-demandaudiovisualservices-PUBLICVERSION-March2015. pdf.

Inside US Trade (2013) After internal battle, commission includes audiovisual services in draft mandate, 21 March. Available at: http://insidetrade.com/Inside-Trade-General/PublicContent/World-Trade-Online/after-internal-battle-commission-includes-AV-services-indraft-mandate/menu-id-896.html.

International Network on Cultural Diversity (INCD) Europe (2009) A first assessment of EU-KOREA FTA protocol on cultural cooperation. (Press release), 26 March. Available at: http://www.eurocinema.eu/docs/EU_Korea_PCC_Assessment_03.09.pdf.

Iosifidis P (2011) Global Media and Communication Policy. London: Palgrave Macmillan.

Lescure P (2013) Mission Acte II de l'exception culturelle: Contribution aux politiques culturelles à l'ère numérique [Act 2 of the Cultural Exception: Contribution to the Cultural Policies in the Digital Era]. Paris: French Ministry of Culture.

Le Sourd M, Di Federico E and Yoon SW (2012) EU-South Korea current trends of cultural exchanges and future perspectives. European expert network on culture report. Brussels: European Expert Network on Culture, November (partially updated, September 2013).

Lickova M (2014) The CDCE in the European Union - A mixed agreement and its judicial application. In: Richieri Hanania L (ed.) Cultural Diversity in International Law: The Effectiveness of the UNESCO Convention on the Protection and Promotion of the Diversity of Cultural Expressions. London: Routledge, pp. 225-237.

Loisen J and De Ville F (2011) The EU-Korea protocol on cultural cooperation: Toward cultural diversity or cultural deficit? International Journal of Communication 5: 254-271.

Neuwirth RJ (2013) The future of the culture and trade debate: A legal outlook. Journal of World Trade 47: 391-420.

Panebianco S (2006) The constraints on EU action as a 'norm exporter' in the Mediterranean. In: Elgstrom O and Smith M (eds) The European Union's Roles in International Politics: Concepts and Analysis. London: Routledge, pp. 136-154.

Pauwels C and Donders K (2014) From television without frontiers to the digital big bang: The EU's continuous efforts to create a future-proof internal media market. In: Mansell M and Raboy M (eds) The Handbook of Global Media and Communication Policy. West Sussex: Wiley Blackwell, pp. 525-542.

Psychogiopoulou E (2012) The Convention on the diversity of cultural expressions and the European Union: The quest for competence and implementation. In: Kono $\mathrm{T}$ and Van Uytsel S (eds) The UNESCO Convention on the Diversity of Cultural Expressions: A Tale of Fragmentation in International Law. Cambridge; Antwerp; Portland, OR: Intersentia, pp. $365-394$. 
Psychogiopoulou E (2014) The external dimension of EU cultural action and free trade: Exploring an interface. Legal Issues of Economic Integration 41(1): 65-86.

Republic of Korea-European Union (EU) (2011) Protocol on cultural cooperation. Official Journal of the European Union. Available at: http://eur-lex.europa.eu/LexUriServ/LexUriServ.do?ur $\mathrm{i}=\mathrm{OJ}: \mathrm{L}: 2011: 127: 1418: 1426: \mathrm{EN}: \mathrm{PDF}$.

Richieri Hanania L (2012) Cultural diversity and regional trade agreements: The European Union experience with cultural cooperation frameworks. Asian Journal of WTO \& International Health Law and Policy 22(2): 423-456.

Richieri Hanania L and Ruiz Fabri H (2014) European media policy and cultural diversity at the international level: The EU's role in fostering the implementation of the 2005 UNESCO convention. In: Donders K, Pauwels C and Loisen J (eds) The Palgrave Handbook of European Media Policy. London: Palgrave Macmillan, pp. 493-508.

Sarikakis K and Ganter S (2014) Priorities in global media policy transfer: Audiovisual and digital policy mutations in the EU, MERCOSUR and US triangle. European Journal of Communication 29(1): 17-33.

Scoffier A (2014) Coproducing in Europe: An economic solution or an artistic choice? INA Global (electronic review). Available at: http://www.inaglobal.fr/en/cinema/article/coproducingeurope-economic-solution-or-artistic-choice-7485 (accessed 7 January 2016).

Smith ME (2011) Implementation: Making the EU's international relations work. In: Hill C and Smith M (eds) International Relations and European Union. Oxford: Oxford University Press, pp. 171-193.

Souyri-Desrosier C (2014) EU protocols on cultural cooperation: An attempt to promote and implement the CDCE within the framework of bilateral trade negotiations. In: Richieri Hanania L (ed.) Cultural Diversity in International Law: The Effectiveness of the UNESCO Convention on the Protection and Promotion of the Diversity of Cultural Expressions. London: Routledge, pp. 209-224.

Strange S (1996) The Retreat of the State: The Diffusion of Power in World Economy. Cambridge: Cambridge University Press.

Thiec Y (2003) Les relations entre les États-Unis et l'Union européenne en matière de politique audiovisuelle [The relationship between United States and European Union in terms of audiovisual policy]. In: Sojcher F and Benghozi PJ (eds) Quel modèle audiovisuel européen? [Which European Audiovisual Model?]. Paris: L'Harmattan, pp. 119-131.

Troussard X, Panis-Cendrowicz V and Guerrier J (2012) Article 16: Preferential treatment for developing countries. In: Schorlemer VS and Stoll PT (eds) The UNESCO Convention on the Protection and Promotion of the Diversity of Cultural Expressions: Explanatory Notes. New York: Springer, pp. 405-455.

United Nations Educational, Scientific and Cultural Organization (UNESCO) (2014) Intergovernmental Committee for the Protection and Promotion of the Diversity of Cultural Expressions: Decisions. CE/14/8.IGC/Dec. prov, 11 December. Paris: UNESCO.

United States International Trade Commission (2014) Recent trends in U.S. services trade: 2014 annual report. Publication number: 4463, May. Washington, DC: United States International Trade Commission.

US Congress (2014) Bipartisan Congressional Trade Priorities Act of 2014. H.R.3830, 9 January. Washington, DC: US Congress.

Vlassis A (2011) La mise en æeuvre de la Convention sur la diversité des expressions culturelles: Portée et enjeux de l'interface 'commerce-culture' [The implementation of the Convention on diversity of cultural expressions: Scope and stakes of the 'trade-culture' interface]. Etudes internationales 42(4): 493-510. 
Vlassis A (2014) Le numérique, nouvelle frontière de la gouvernance mondiale des industries culturelles? [The digital technology, new frontier of the global governance of cultural industries?]. Revue de la Faculté de droit de l'Université de Liège 59(2): 283-300.

Vlassis A (2015a) Gouvernance mondiale et culture: de l'exception à la diversité [Global Governance and Culture: From Exception to Diversity]. Liège: Presses Universitaires de Liège.

Vlassis A (2015b) Soft power, global governance of cultural industries and rising powers: The case of China. International Journal of Cultural Policy. Epub ahead of print 28 January. DOI: 10.1080/10286632.2014.1002487.

Vlassis A and Richieri Hanania L (2014) Effects of the CDCE on trade negotiations. In: Richieri Hanania L (ed.) Cultural Diversity in International Law: The Effectiveness of the UNESCO Convention on the Protection and Promotion of the Diversity of Cultural Expressions. London: Routledge, pp. 25-39.

Vogler J (2011) The challenge of the environment, energy, and climate change. In: Hill C and Smith M (eds) International Relations and European Union. Oxford: Oxford University Press, pp. 349-379. 